\author{
В.В. Свдокимов, д.е.н., проф. \\ О.В. Олійник, д.е.н., проф. \\ А.В. Морозов, к.т.н., доц. \\ А.О. Чагайда, к.т.н., доц. \\ Державний університет «Житомирська політехніка»
}

\title{
Житомирська політехніка: 100 років від початку технічної освітньої діяльності
}

Сто років тому Народним комісаріатом освіти України було прийнято рішення про ліквідацію навчальних закладів, що існували за часів «буржуазного режиму» та оголошено новий підхід у формуванні системи освіти. Результати цієї діяльності відображено у працях безпосередніх учасників подій - Г.Гринька, Я.Ряппо, Я.Звігальського. Ці зміни вплинули на організацію i розвиток вузькопрофільної індустріальної освіти в різних регіонах України та призвели до відкриття у м. Житомирі першого вищого інженерно-технічного закладу у Волинській губернії - Волинського індустріального технікуму. Історії створення навчальних закладів м. Житомира, в тому числі закладів вищої освіти, присвячено роботи Г.П. Мокрицького, Р.Ю. Кондратюка, Н.В. Рудницької.

Метою дослідження $\epsilon$ аналіз організації і розвитку вузькопрофільної інженерно-технічної освіти на Житомирщині у 20-х роках XX сторіччя та висвітлення діяльності єдиного у Волинській губернії вищого навчального закладу такого профілю - Волинського (Житомирського) індустріального технікуму.

У березні 1920 року, коли в Україні тривала громадянська війна, а у Житомирі ще кілька разів змінювалася влада, групою викладачів Житомирського землемірного училища було створено перший інженерно-технічний заклад освіти Волинської губернії - Волинський земельний політехнікум. Політехнікум мав у своєму складі три відділення - електротехнічне, сільськогосподарських технологій та гідротехнічне, навчання на яких відбувалося лише 3 теоретичних дисциплін (вища математика, теоретична механіка тощо) без будь-якої практичної підготовки. Рівень теоретичного викладання був достатньо високим завдяки високопрофесійним викладачам, серед яких проф. Сокольцов, інженери Грязнов, Кандалінцев та інші [1]. У листопаді 1920 року колегія підвідділу професійної освіти Волинської губернії для реорганізації Політехнікуму створила комісію, яка мала негайно розібратися 3 документами та доповісти про відповідність і тип навчального закладу [2]. Вже за два тижні Губпрофос, на підставі доповіді голови комісії Й.І. Чеховського, ухвалив рішення про відкриття у Волинському індустріальному технікумі (ВІТ) таких відділень: 1) механічної технології; 2) будівельного; 3) хімічної технології. В технікумі мали навчатися 250-300 слухачів, при цьому половину мали складати мешканці м. Житомира, а іншу частину - представники повітів [3].

Органи Волинської губернської професійної освіти до весни 1921 року ще не запрацювали повною мірою, тому в березні 1921 року група студентів Волинського технікуму, через невизначеність із підпорядкуванням навчального закладу, звернулася 3 листом до Народного комісара освіти України Г.Ф. Гринька. Студенти зазначають, що протягом тих півтора місяця 1920 року, коли Житомир знаходився під польською владою, вимушені були нелегально збиратися на лекції фахівців, які погодилися продовжити викладання, а зміна влади не покращила становища навчального закладу, який так остаточно і не передали із підпорядкування губернського земельного відділу до відділу професійної освіти. За такого становища місцеві чиновники з початком 1920/21 навчального року відмовились оплачувати роботу лекторів, не визнаючи себе відповідальними за навчальний заклад, і тому цей період в історії технікуму можна назвати «періодом благодійності» [4].

Колишні викладачі земельного політехнікуму - Шпігель Софія Абрамівна, Пікман Борис Мойсейович, Ріненберг Роберт Олексійович, Платонов Анатолій Сергійович та інші читали лекції в індустріальному технікумі через співчуття до молоді, тому що винагорода за роботу була мізерною, а продовольчі пайки не відпускалися. Ряд дисциплін викладати просто було неможливо через відсутність лабораторій та дощок в аудиторіях. Весною, з початком городньої кампанії, голодуючі викладачі 3 головою поринали в обробку земельних ділянок, де їх і знаходили посланці від студентства [5].

Реагуючи на лист студентів, відповідне рішення про долю ВІТу було прийнято 28 березня 1921 року другим заступником Наркому освіти Я.Ряппо, який визначив статус та підпорядкування Волинського індустріального технікуму: «Колишній Житомирський земельний політехнікум вважати технікумом із безпосереднім підпорядкуванням Губернському відділу професійної освіти. Заклад має усі права технікуму і повинен працювати за навчальними планами технікумів, а також має негайно надати навчальні плани, програми та кошторис по фінансах і матеріалах» [4].

Влітку 1921 року колегія Губпофосу проводила запеклі дебати щодо подальшої долі технікуму і у вересні цього року прийшла до рішення про можливість закриття навчального закладу. Це не було сприйнято студентами та частиною викладачів, і рішенням центральних органів влади технікум було 
збережено в мережі Волинського губпрофосу на 1921/22 навчальний рік [5]. У результаті Губпрофос делегує свого представника на посаду керуючого технікумом і з 13 вересня 1921 року інженер Суботін Михайло Петрович очолив навчальний заклад, при цьому колишній завідувач (з листопада 1920 по вересень 1921 року) Чеховський Йосип Іванович став його заступником та керуючим навчальною частиною [6].

Інженер М.Суботін отримав вищу освіту у Миколаївській військово-інженерній академії СанктПетербурга (1909р.), де під керівництвом проф. Е.Ю. Лундберга виконав дипломний проект «Каналізація і біологічне очищення стічних вод м. Катеринослава», за захист якого був відзначений премією імені інженера П.С. Березіна. Після завершення навчання виконував роботи спочатку в м. Києві на будівництві каналізації, а потім, починаючи з 1912 року, працював у м. Владивосток: 2 роки у будівельно-господарському відділенні та ще 2 роки виконробом на будівництві доріг і залізобетонних мостів. У цей же час на будівництво у м. Владивосток Академією наук було направлено геолога П.В. Віттенбурга, наукові праці якого викликали у М.Суботіна зацікавленість до науково-дослідної роботи з мінералогії. У 1915-1916 роках М.Суботін здійснив спробу змінити професію будівельника на географа-дослідника і вступив на щойно відкриті Санкт-Петербурзькі вищі географічні курси, але війна та революція не дали можливості їх завершити. 3 жовтня 1917 року займався науковою роботою в Житомирі, і коли з'явилася вакансія інструктора профосвіти в шкільній раді Волинського губернського земства, то розпочав діяльність у галузі освіти і з осені 1919 року викладав спеціальні дисципліни у I та II профтехнічних школах м. Житомира. Захоплення міста поляками, наступне перебування в лавах Червоної Армії до кінця 1920 року, повернення в Житомир на початку 1921 року і робота у Волинській губернській раді профспілок перервали освітню діяльність М.Суботіна. Саме цю людину Губернська рада профспілок делегувала на посаду завідувача, щоб не допустити закриття Волинського технікуму.

Частина студентів і викладачів 3 недовірою поставилася до можливості налагодження роботи технікуму новим керівником, але 11 жовтня було проведено вступні випробування і 325 жовтня 1921 року розпочались аудиторні заняття. Станом на початок 1921/22 навчального року в технікумі навчався 231 студент: 99 - на механічному факультеті, 26 - на будівельному, 44 - на хімічному і 62 на підготовчому. Хоча губернська рада профспілок і губернська рада народного господарства підтримували технікум і його нового керівника, більшість лекторів голодували, не було дров для опалення аудиторій і бібліотеки. Для нормалізації роботи ВІТу губернський комітет постачання гарантував викладацькому персоналу незначну кількість академпайків, Рада Народного Господарства передала черепично-бетонний завод, а губернський виконком виділив 1700000 карбованців на ремонт хімічної лабораторії [5]. Укрголовпрофобр, розглянувши звіт за 1921 рік про стан індустріальної освіти у Волинській губернії, зосередив увагу губернського відділу на необхідних змінах у навчальному процесі, надавши технікуму «більш виробничого характеру, звільнивши його від університетського нальоту та енциклопедизму шляхом зменшення кількості лекцій, а також знищення інституту вільних слухачів». Зверталась увага керівництва технікуму на необхідності збільшення «пролетарської частини студентства», що становила усього $3,9 \%$ (2,2 \% робітників і 1,7 \% селян) та відсутність чіткого розуміння завдань і мети технікуму. Особливе занепокоєння викликала нестача викладачів для підготовки інженерів вузької спеціалізації та відсутність програм окремих дисциплін [7].

Згідно 3 «Положенням про проведення перереєстрації студентів», розробленим колегією Головпрофосвіти у листопаді 1921 року, перша перереєстрація, проведена серед студентів України, «звільнила школу від величезної кількості "мертвих душ", що рахувалися в вузах у списках, але фактично там не працювали, а також від наявно непридатного баласту», в результаті чого із вищих навчальних закладів було виключено 11 тисяч студентів [8]. Бюро студкому Волинського індустріального технікуму також створює «трійку», яка на відкритих зібраннях проводить «чистку» студентства [9]. Ці чистки відбувалися неодноразово з метою відрахування «соціально несвідомих елементів». Так в результаті чергової перереєстрації 157 студентів «трійка» констатує, що більшість із тих, хто навчається, вже є представниками пролетарського середовища з великим відсотком звільнених 3 Червоної Армії. Частину представників дрібної буржуазії було виключено з технікуму, а іншим встановлено найвищу норму сплати за навчання. Для тих студентів, які не з'явилися на переатестації (15 осіб), було прийнято рішення про виключення їх з технікуму, а також виключено ще 13 осіб, яких було визнано: баластом - 5 осіб; кулаками та дрібною буржуазією - 4 особи; такими, що ухиляються від служби в армії шляхом перебування в технікумі - 3 особи; того, що служив у білогвардійців 1 особа [10]. У травні 1922 року Волинська губернська Рада професійних спілок підтверджує особливу важливість Волинського індустріального технікуму як єдиного індустріально-технічного навчального закладу губернії, що орієнтований на ударні галузі виробництва, і для покращення роботи якого було передано лабораторію та завод. Проведення перереєстрації студентів та забезпечення з вересня 1921 року кваліфікованих викладачів пайками дозволило технікуму досягти рівня 3 кваліфікацією «вищого» як за показниками викладання дисциплін, так і за якістю виховної роботи та складу студентів, очищених від ворожих елементів [11]. 
Керівництво технікуму у 1921/22 навчальному році приділило значну увагу якісному підбору викладачів: станом на травень 1922 року 24 із 25 лекторів мали вищу освіту, в т. ч. 12 - інженерну, а дипломи закордонних навчальних закладів про вищу освіту мали 5 лекторів [12]. Так інженер-механік Флор Якович Кашкадаєв, у недалекому минулому головний інженер одного з найбільших у Житомирі підприємств - чавуно-ливарного та механічного заводу Вайнштейна (відомий житомирянам як завод «Автозапчастина»), окрім керівництва механічним факультетом ВІТу, ще був завідуючим Житомирською ремісничою школою; математики Роберт Рінненберг та Володимир Барицький - обидва не лише педагоги з великим стажем, а й $з$ науковими ступенями; Олександр Тугенгольд - не лише юрист за освітою, але ще і чудовий художник та кресляр; Михайло Кудрицький - фізик, метеоролог, представник знаменитої житомирської родини Кудрицьких, четверо 3 яких увійшли до «Української радянської енциклопедії». В цілому на початок 1920-х років при технікумі зосередилися залишки, вцілілої у революційному вихорі, науково-технічної та педагогічної еліти Житомира та Волині [13].

Одним із перших, кого у 1921 році було залучено до викладання в технікумі, був відомий геолог та топограф Степан Володимирович Бєльський (Більський), що від 1907 року досліджував корисні копалини Волинської губернії та 31910 року був головою природничої секції Товариства дослідників Волині і засновником геологічного відділу при Волинському центральному музеї. На хімічному факультеті ВІТу С.В. Бєльський викладав курси кристалографії, мінералогії та місцевих копалин [14], але одночасно не припиняв керівництво Волинськими гірничорозвідувальними партіями. Зроблені у 1923 році дослідження для Всеукртресту «Фарфор - Фаянс - Скло» докорінним чином змінили погляд на сировинне господарство та використання надр (було знайдено родовище каоліну, який на той час для виробництва привозили із Таврійської губернії). Бєльский С. разом із керуючим ВІТом М.Суботіним, переконали керівництво тресту у доцільності лабораторних досліджень добутих під час експедиції зразків безпосередньо в Житомирі, для чого було передбачено створення при технікумі навчальнонаукової лабораторії [15]. У подальшій освітній діяльності Бєльського С.В., на підставі постанови кваліфікаційної комісії при ДНМК з 23/XI-27 р. прот. Ч. 29, було затверджено штатним професором II гр. по геології та мінералогії в Житомирському індустріальному технікумі [16].

Згідно із затвердженим у 1922 році Кодексом законів про народну освіту УСРР, в основній системі інженерно-технічної освіти виокремлювалося два типи вищих навчальних закладів - інститути і технікуми, що належали до одного освітнього рівня, але мали різне цільове призначення [17]. Так інститут був політехнічним навчальним закладом і готував інженерів-організаторів, керівників широкої галузі народного господарства із поглибленим іiі знанням, 3 глибокою науково-технічною та економічною підготовкою. Технікум в основному мав один факультет і готував працівників вищої кваліфікації (інженерів-практиків, агрономів, сільськогосподарських працівників) окремої вузької галузі народного господарства і державного будівництва [18].

За результатами аналізу роботи технікуму у травні 1922 року Волгубпрофос звернувся з клопотанням зареєструвати існуючий у м. Житомир технікум у загальноукраїнській профшкільній мережі [12] і у серпні 1922 року технікум було внесено до списку індустріально-технічних закладів України [19], а також 13 вересня 1922 року індустріально-технічним відділом Укрголовпрофосу в Харкові було затверджено тимчасові навчальні плани [20] для трьох факультетів технікуму: хімічного (спеціальності технолог шкіряного, цукрового, фарфор-фаянс-скляного виробництва), будівельного (спеціальності дороги, мости 3 включенням елементів комунального будівництва) і механічного (спеціальності сільськогосподарське машинобудування і машинознавство) [21]. Весь процес навчання був розбитий на 9 триместрів і тривав не більше 10 місяців на рік (по 3 триместри). Під час літнього триместру обов'язковою була виробнича практика: студенти хімічного факультету під час практики працювали на фарфорових заводах, практично проходили усі стадії виробництва, а також брали участь у геологічній розвідці під керівництвом проф. С.В. Бєльського [22].

У той самий час технікум не мав власного приміщення і займав лише один поверх у будинку Волинського IHO (колишня Перша гімназія Житомира, вул. К.Маркса), де знаходились аудиторії технікуму, викладацька, канцелярія і бібліотека. Практичні заняття проводились: у I механічній профшколі (вул. Московська, 45); в будівельній профшколі (Бердичівське шосе, 3); в хімічній лабораторії (вул. К.Маркса, 13); в приміщеннях черепично-бетонного заводу, де була лабораторія по випробуваннях будівельних матеріалів та бетонні майстерні (Бердичівське шосе). Для покращення навчального процесу у вересні 1922 року було прийнято рішення про передачу будівлі колишньої Другої чоловічої гімназії м. Житомира для розміщення Волинського індустріального технікуму. Триповерхова будівля була збудована у 1882 році як навчальний корпус Житомирського єврейського учительського інституту. Після закриття інституту у 1886 році і капітального ремонту будівлі у 1890 році в ній було розміщено прогімназію, яка згідно із царським указом з 1 липня 1897 року поступово була перетворена в гімназію (31 серпня відбулось урочисте відкриття Другої Житомирської чоловічої гімназії). Гімназія діяла до 1919 року і з остаточним поверненням більшовиків до Житомира будівлю зайняли військові [23]. На момент прийняття рішення про передачу будівлі колишньої Другої гімназії м. Житомира Волинському 
індустріальному технікуму в іiї приміщеннях розташовувалися курси червоних командирів 44-ї дивізії, i звільнення будівлі постійно відкладалося і затягувалося [24]. Станом на червень 1923 року технікум повністю займав лише другий поверх будівлі та кілька кімнат на першому і третьому поверхах, що могло негативно вплинути на початок нового навчального року [25]. На запит Ради Народних Комісарів УССР (№ 14151) начальник інженерів Українського військового округу 21 серпня 1923 року категорично наказав командиру 44-ї дивізії негайно звільнити приміщення 2-ї чоловічої гімназій в м. Житомирі і передати ії технікуму [26], що було офіційно зроблено та підтверджено актом від 4-го вересня 1923 року про передачу будівлі та надвірних споруд садиби на вул. Пушкінській, 38 у розпорядження BITу [27]. Процес звільнення окремих приміщень на цьому не завершився і ще тривав до 21 вересня, що вплинуло на проведення необхідних ремонтних робіт та унеможливило діяльність бібліотеки протягом трьох 3 половиною місяців [28]. Виділених Народним комісаріатом освіти 50000 крб на ремонт будівлі виявилось абсолютно недостатньо, через що додатково на ці потреби у 1923 році було витрачено частину оплати студентів за навчання у кількості 502129 крб 95 коп.

Отримавши у власність будівлю, технікум, окрім аудиторій, одразу розмістив там хімічну лабораторію (з окремими відділами для аналітичного, кількісного і якісного аналізу), аудиторію для креслень, геологічний музей, лабораторію для випробування будівельних матеріалів, бібліотеку та виділив окреме приміщення для створення лабораторії керамічного виробництва. Частину аудиторій тимчасово було надано хімічній профшколі, яка проводила там заняття у першій половині дня, а у вечірній час там навчалися студенти технікуму. В головній будівлі найбільшу залу, що вміщувала 200 осіб, віддали під клуб, де силами студентів було змонтовано сцену. Одне із приміщень на території садиби використовувалося для проживання студентів з інших міст, в тому числі 14 студентів, які прибули з розформованого Уманського будівельного технікуму [29].

Проблеми із викладацькими кадрами та відсутність стратегії розвитку призвели до масового закриття значної кількості навчальних закладів у перші ж роки після їх створення, в результаті чого кількість технікумів у Україні стабілізувалася лише станом на кінець 1924 року. Студенти Чернігівської політехнічної школи, Ніжинського хіміко-механічного технікуму, Чернігівського індустріально-агрономічного технікуму, Мироцького технологічного технікуму постановами Головпрофосвіти були переведені до Волинського індустріального технікуму для завершення навчання і отримання свідоцтв інженерів відповідного фаху. Затвердження у квітні 1924 року нових навчальних планів ВІТу завершило етап визначення основних напрямів освітньої діяльності навчального закладу, що передбачало підготовку фахівців таких спеціалізацій на 3 факультетах: на механічному факультеті - теплотехніка, сільськогосподарські машини, гідромеханіка; на будівельному факультеті - шляхи, комунальне будівництво; на хімічному факультеті - кераміка, хімічні виробництва, технологія органічних речовин [30, 31].

Висновки. Більшість закладів освіти індустріального спрямування були створені одразу після воєнних дій 1917-1920 років через проблеми із кваліфікованими кадрами для відродження економіки. На початковому етапі своєї історії Волинський індустріальний технікум мав великі проблеми із формуванням викладацького складу та пошуками свого місця в освітньому просторі, адже для якісного здійснення навчального процесу необхідні були спеціалізовані лабораторії та майстерні для проходження практичної підготовки. Хоча система вищої освіти передбачала вузькопрофільну підготовку інженерів у технікумах за однією спеціальністю, діяльність Волинського індустріального технікуму свідчить, що Головінспектура інженерно-технічної освіти надавала дозволи на підготовку більшої кількості спеціальностей та спеціалізацій, враховуючи особливу важливість закладу освіти для регіону.

\section{Список використаної літератури:}

1. Свдокимов В.В. Становлення Волинського (Житомирського) індустріального технікуму як єдиного вищого технічного навчального закладу Волинської губернії / В.В. Євдокимов, О.В. Олійник, А.О. Чагайда // Наукове видання Державного університету «Житомирська політехніка». Серія : Технічна інженерія. Житомир, 2019. - № 2 (84). - С. 3-9.

2. Протокол № 3 заседания коллегии подотдела проф. образования // Державний архів Житомирської області. - Ф. 31, оп. 1, спр. 10, арк. 50.

3. Протокол № 4 заседания коллегии подотдела проф. образования // Державний архів Житомирської області. - Ф. 31, оп. 1, спр. 10, арк. 48.

4. Докладная записка слушателей Волынского техникума Наркомпросу т. Гринько // ЦДАВО України. Ф. 166, оп. 1, спр. 1023, арк. 15-18.

5. Отчет о состоянии Волынского индустриального техникума на 1 января 1922 г. // ЦДАВО України. Ф. 166, оп. 2, спр. 1330, арк. 40.

6. ИТО Укрглавпрофорбра. 30 августа 1922 г. // ЦДАВО України. - Ф. 166, оп. 2, спр. 1329, арк. 34.

7. Волынскому Губпрофобру 10.05.1922. № 427// ЦДАВО України. - Ф. 166, оп. 2, спр. 1328, арк. 12.

8. Ряппо Я.П. Радянське студентство (характеристика вузів України) / Я.П. Ряппо // Державне видавництво України, 1928. - 48 с.

9. Протокол заседания бюро студкома // ЦДАВО України. - Ф. 166, оп. 2, спр. 1329, арк. 14. 
10. Сведения о заключении комиссии // ЦДАВО України. - Ф. 166, оп. 2, спр. 1330, арк. 98.

11. В культпросветотдел юрбюро В.У.С.П.С. // ЦДАВО України. - Ф. 166, оп. 2, спр. 1329, арк. 20.

12. Заключение Волгубпрофобра о состоянии и квалификации Волынского индустриального техникума. 13 мая 1922 г. № 674 // ЦДАВО України. - Ф. 166, оп. 2, спр. 1329, арк. 15.

13. Кондратюк Р. Житомирська політехніка - початок технічної освіти на Житомирщині / Р.Кондратюк [Електронний ресурс]. - Режим доступу : https://www.zhitomir.info/news_189947.html.

14. Состав преподавателей (именной список всех преподавателей, руководителей практическими занятиями) заведывающих кабинетами, лабораториями // ЦДАВО України. - Ф. 166, оп. 2, спр. 1329, арк. 124.

15. Богатства Волыни. Исследование волынских недр (из отчета горно-разведочной партии Волыни ФарфорТресту) // ЦДАВО України. - Ф. 166, оп. 2, спр. 1330, арк. 35-35.

16. Витяг з розпорядження по Управлінню професійної освіти в справі призначення та звільнення штатної лектури вузів УСРР. 3 дня 6-го грудня 1927 р. К-17 // ЦДАВО України. - Ф. 166, оп. 6 II, спр. 3718, арк. 73.

17. Про надання чинності Кодексу Законів про народну освіту : Постанова ВУЦВК від 22 листопада 1922 р. // Собрание узаконений и распоряжений рабоче-крестьянского правительства Украины. - 1922. - № 49. - С. 884.

18. Проект звітної доповіді про роботу Головпрофосу Наркомосу УРСР за 1924-1925 pр. // ЦДАВО України. Ф. 166 , оп. 5 , спр. 522, арк. 5.

19. Проект звітної доповіді про роботу Головпрофосу Наркомосу УРСР за 1924-1925 pp. // ЦДАВО України. Ф. 166, оп. 2, спр. 338, арк. 43-47.

20. Отчет Волынского индустриального техникума за 1922/23 уч. год. Общие сведения об учебной работе // ЦДАВО України. - Ф. 166, оп. 2, спр. 1330, арк. 11.

21. Вр. Учебный план // ЦДАВО України. - Ф. 166, оп. 2, спр. 1330, арк. 30-32.

22. Краткий отчет о практике студентов химического факультета ВИТа: Квитко, Гак, Демидов // ЦДАВО України. - Ф. 166, оп. 2, спр. 1330, арк. 21-23.

23. Мокрищький Г.П. Пушкінська, 42: історія будинку : архіт.-краєзн. нарис / Г.П. Мокрицький. - Житомир : Волинь, 2001. - 32 с.

24. ИТО Укргавпрообра. Памятка по поводу зданий. 15.09.1922 г. исх. № 337 // ЦДАВО України. - Ф. 166, оп. 2, спр. 1329 , арк. 35

25. ИТО Укргавпрообра. В дополнение телеграммы. 28.06.1923 г. исх. № 541 // ЦДАВО України. - Ф. 166, оп. 2, спр. 1329, арк. 110.

26. Управление делами Совета Народных Комиссаров УССР. 21.08.1923 г. исх. № 261254. Харьков // ЦДАВО України. - Ф. 166, оп. 2, спр. 1329, арк. 117.

27. Акт от 4 сентября 1923 года // ЦДАВО України. - Ф. 166, оп. 2, спр. 1329, арк. 135.

28. Отчет Волынского индустриального техникума за 1922/23 уч. г. IV. Общие сведения хозяйственной жизни учебного заведения // ЦДАВО України. - Ф. 166, оп. 2, спр. 1330, арк. 7.

29. Отчет Волынского индустриального техникума за осенний триместр 1923/24 уч. г. IV. Общие сведения о хозяйственной жизни учебного заведения // ЦДАВО України. - Ф.166, оп. 2, спр. 1330, арк. 120-121.

30. Євдокимов B.B. Становлення вищої технічної школи в Україні у 20-ті роки ХХ сторіччя / В.В. Свдокимов, O.B. Олійник, A.O. Чагайда // Наукове видання Державного університету «Житомирська політехніка». Серія : Економіка, управління та адміністрування. - Житомир, 2019. - № 3 (89). - С. 3-7.

31. Учебный план Волынского индустриального техникума имени Ленина // ЦДАВО України. - Ф. 166, оп. 2, спр. 1330, арк. 101.

\section{References:}

1. Jevdokymov, V.V., Olijnyk, O.V. and Chagajda, A.O. (2019), «Stanovlennja Volyns'kogo (Zhytomyrs'kogo) industrial'nogo tehnikumu jak jedynogo vyshhogo tehnichnogo navchal'nogo zakladu Volyns'koi' gubernii'», Naukove vydannja Derzhavnogo universytetu «Zhytomyrs'ka politehnika», Serija «Tehnichna inzhenerija Zhytomyr» No. 2 (84), pp. 3-9.

2. Derzhavnyj arhiv Zhytomyrs'koi' oblasti, Protokol No. 3 zasedanija kollegii podotdela prof. Obrazovanija, F. 31, op. 1, spr. 10, ark. 50.

3. Derzhavnyj arhiv Zhytomyrs'koi' oblasti, Protokol No. 4 zasedanija kollegii podotdela prof. Obrazovanija, F. 31, op. 1, spr. 10, ark. 48.

4. CDAVO Ukrai'ny, Dokladnaja zapiska slushatelej Volynskogo tehnikuma Narkomprosu t. Grin'ko, F. 166, op. 1, spr. 1023, ark. 15-18.

5. CDAVO Ukrai'ny, Otchet o sostojanii Volynskogo industrial'nogo tehnikuma na 1 janvarja 1922 g., F. 166, op. 2, spr. 1330 , ark. 40.

6. CDAVO Ukrai'ny, ITO Ukrglavproforbra. 30 avgusta 1922 g., F. 166, op. 2, spr. 1329, ark. 34.

7. CDAVO Ukrai'ny, Volynskomu Gubprofobru 10.05.1922 ish. No. 427, F. 166, op. 2, spr. 1328, ark. 12.

8. Rjappo, Ja.P. (1928), Radjans'ke studentstvo (harakterystyka vuziv Ukrai'ny), Derzhavne vydavnyctvo Ukrai'ny, 48 p.

9. CDAVO Ukrai'ny, Protokol zasedanija bjuro studkoma, F. 166, op. 2, spr. 1329, ark. 14.

10. CDAVO Ukrai'ny, Svedenija o zakljuchenii komissii, F. 166, op. 2, spr. 1330, ark. 98.

11. CDAVO Ukrai'ny, V kul't-prosvetotdel jurbjuro V.U.S.P.S., F. 166, op. 2, spr. 1329, ark. 20.

12. CDAVO Ukrai'ny, Zakljuchenie Volgubprofobra o sostojanii i kvalifikacii Volynskogo industrial'nogo tehnikuma. 13 maja 1922 g. ish. No. 674, F. 166, op. 2, spr. 1329, ark. 15.

13. Kondratjuk, R. Zhytomyrs'ka politehnika - pochatok tehnichnoi' osvity na Zhytomyrshhyni, [Online], available at: https://www.zhitomir.info/news_189947.html 
14. CDAVO Ukrai'ny, Sostav prepodavatelej (imennoj spisok vseh prepodavatelej, rukovoditelej prakticheskimi zanjatijami) zavedyvajushhih kabinetami, laboratorijami, F. 166, op. 2, spr. 1329, ark. 124.

15. CDAVO Ukrai'ny, Bogatstva Volyni. Issledovanie volynskih nedr (iz otcheta gorno-razvedochnoj partii Volyni Farfor-Trestu), F. 166, op. 2, spr. 1330, ark. 35-35.

16. CDAVO Ukrai'ny, Vytjag z rozporjadzhennja po Upravlinnju profesijnoi' osvity $v$ spravi pryznachennja ta zvil'nennja shtatnoi' lektury vuziv USRR. 6 grudnja 1927 r. K-17, F. 166, op. 6 II, spr. 3718, ark. 73.

17. Sobranie uzakonenij i rasporjazhenij raboche-krest'janskogo pravitel'stva Ukrainy (1922), «Pro nadannja chynnosti Kodeksu Zakoniv pro narodnu osvitu», Postanova VUCVK vid 22 lystop., No. 49, 884 p.

18. CDAVO Ukrai'ny, Proekt zvitnoi' dopovidi pro robotu Golovprofosu Narkomosu URSR za 1924-1925 rr., F. 166, op. 5 , spr. 522, ark. 5 .

19. CDAVO Ukrai'ny, Proekt zvitnoi' dopovidi pro robotu Golovprofosu Narkomosu URSR za 1924-1925 rr., F. 166, op. 2, spr. 338, ark. 43-47.

20. CDAVO Ukrai'ny, Otchet Volynskogo industrial'nogo tehnikuma za 1922/23 uch. god. Obshhie svedenija ob uchebnoj rabote, F. 166, op. 2, spr. 1330, ark. 11.

21. CDAVO Ukrai'ny, Vr. Uchebnyj plan, F. 166, op. 2, spr. 1330, ark. 30-32.

22. CDAVO Ukrai'ny, Kratkij otchet o praktike studentov himicheskogo fakul'teta VITa: Kvitko, Gak, Demidov, F. 166, op. 2, spr. 1330, ark. 21-23.

23. Mokryc'kyj, G.P. (2001), Pushkins'ka, 42: istorija budynku, arhit.-krajezn. narys, Volyn', Zhytomyr, 32 p.

24. CDAVO Ukrai'ny, ITO Ukrgavproobra. Pamjatka po povodu zdanij. 15.09.1922 g. ish. No. 337, F. 166, op. 2, spr. 1329, ark. 35.

25. CDAVO Ukrai'ny, ITO Ukrgavproobra. V dopolnenie telegrammy. 28.06.1923 g. ish. No. 541, F. 166, op. 2, spr. 1329, ark. 110.

26. CDAVO Ukrai'ny, Upravlenie delami Soveta Narodnyh Komissarov USSR. 21.08.1923 g. ish. No. 261254, Har'kov, F. 166, op. 2, spr. 1329, ark. 117.

27. CDAVO Ukrai'ny, Akt ot 4 sentjabrja 1923 g., F. 166, op. 2, spr. 1329, ark. 135.

28. CDAVO Ukrai'ny, Otchet Volynskogo industrial'nogo tehnikuma za 1922/23 uch. god. Obshhie svedenija hozjajstvennoj zhizni uchebnogo zavedenija, F. 166, op. 2, spr. 1330, ark. 7.

29. CDAVO Ukrai'ny, Otchet Volynskogo industrial'nogo tehnikuma za osennij trimestr 1923/24 uch. god. Obshhie svedenija o hozjajstvennoj zhizni uchebnogo zavedenija, F. 166, op. 2, spr. 1330, ark. 120-121.

30. Jevdokymov, V.V., Olijnyk, O.V. and Chagajda, A.O. (2019), «Stanovlennja vyshhoi' tehnichnoi' shkoly v Ukrai'ni u 20-ti roky XX storichchja», Naukove vydannja Derzhavnogo universytetu «Zhytomyrs'ka politehnika» Serija «Ekonomika, upravlinnja ta administruvannja», Zhytomyr, No. 3 (89), pp. 3-7.

31. CDAVO Ukrai'ny, Uchebnyj plan Volynskogo industrial'nogo tehnikuma imeni Lenina, F. 166, op. 2, spr. 1330, ark. 101.

Свдокимов Віктор Валерійович - доктор економічних наук, професор, ректор Державного університету «Житомирська політехніка».

Наукові інтереси:

- проблеми національної економічної безпеки;

- розвиток вищої освіти в Україні.

Олійник Оксана Вікторівна - доктор економічних наук, професор, перший проректор Державного університету «Житомирська політехніка».

Наукові інтереси:

- обліково-аналітичне забезпечення системи управління;

- розвиток вищої освіти в Україні.

Морозов Андрій Васильович - кандидат технічних наук, доцент, доцент Державного університету «Житомирська політехніка».

Наукові інтереси:

- розвиток вищої освіти в Україні.

Чагайда Андрій Олегович - кандидат технічних наук, доцент кафедри туризму та готельноресторанної справи Державного університету «Житомирська політехніка».

Наукові інтереси:

- проблеми теорії та практики технології виробництва на підприємствах харчової промисловості;

- мінітехнології на підприємствах готельно-ресторанного господарства;

- розвиток вищої освіти в Україні. 